\title{
Reducing early and unintended pregnancies among adolescents
}

\author{
Francis Obare \\ Population Council \\ Caroline W. Kabiru \\ Population Council \\ Venkatraman Chandra-Mouli
}

Follow this and additional works at: https://knowledgecommons.popcouncil.org/departments_sbsr-rh

Part of the Demography, Population, and Ecology Commons, Family, Life Course, and Society Commons, International Public Health Commons, Maternal and Child Health Commons, and the Women's Health Commons How does access to this work benefit you? Let us know!

\section{Recommended Citation}

Obare, Francis, Caroline W. Kabiru, and Venkatraman Chandra-Mouli. 2018. "Reducing early and unintended pregnancies among adolescents," Family Planning Evidence Brief. Geneva: World Health Organization. 


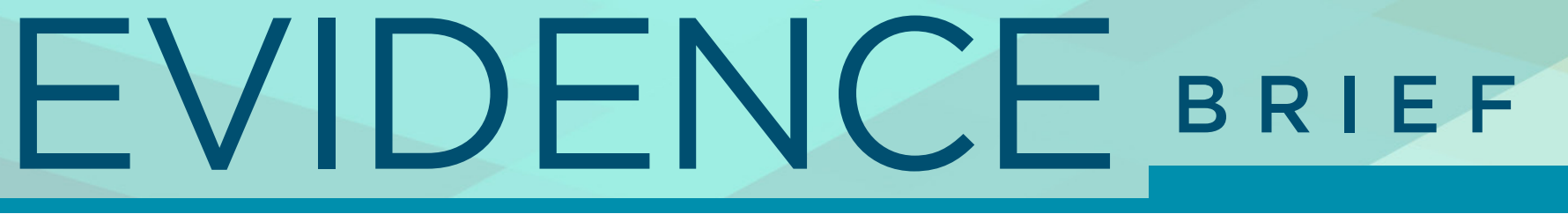

\section{Reducing early and unintended pregnancies among adolescents}

\section{$\rightarrow$ Interventions to reduce unmet need for contraception and early and unintended pregnancies among adolescents should be critical components of family planning programmes in developing countries.}

The 1.2 billion adolescents aged 10-19 years around the world make up $16 \%$ of the world's population (1). The majority ( $86 \%$ ) of adolescents live in developing countries. By the time they are 19 years old, half of adolescent girls in developing countries are sexually active, about $40 \%$ are married, and close to $20 \%$ have children (2).

There were 21 million pregnancies among adolescent girls aged 15-19 years in developing countries in 2016; nearly half (49\%) were unintended (43\% in Asia, 45\% in Africa, and 74\% in Latin America and the Caribbean) (2). An estimated 12 million girls aged 15-19 gave birth. Additionally, 777,000 girls under the age of 15 gave birth in the same year (3). An estimated 23 million adolescent girls have an unmet need for modern contraception and are at risk of unintended pregnancy (2). About onefifth $(21 \%)$ of unintended adolescent pregnancies in Asia, and about half of unintended pregnancies in Latin America and the Caribbean (49\%) and in Africa (46\%) end in unsafe abortion (4).

Early and unintended pregnancy among adolescent girls is influenced by contextual factors at the individual, interpersonal, community, and societal levels. It is also associated with adverse health, educational, social, and economic outcomes that may impose a substantial burden on the economies and health systems of developing countries (1, 5-12). Repeat pregnancy amongst adolescents can compound these adverse outcomes (13).

Interventions that combine demand-creation activities and provision of contraceptive services have the potential to increase contraceptive uptake among adolescents (14-17). Both the demand for and supply of contraceptives to adolescents can, however, be negatively influenced by several barriers that require appropriate programmatic responses.

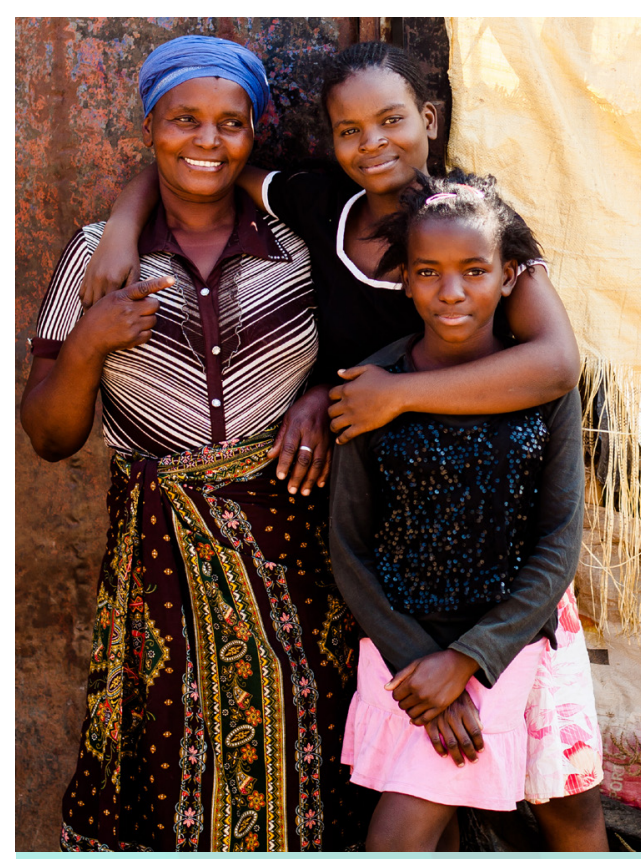

POLICY AND PROGRAMME CONSIDERATIONS

$\rightarrow$ Collect, analyse, and use accurate and up-to-date data.

$\rightarrow$ Formulate or revise national laws and policies.

$\rightarrow$ Develop national adolescent sexual and reproductive health strategies.

$\rightarrow$ Implement strategies with careful monitoring.

$\rightarrow$ Conduct periodic programme reviews. 
Table 1. Barriers and potential approaches to increase the demand for and supply of contraception among adolescents

\begin{tabular}{|c|c|c|c|}
\hline $\begin{array}{l}\text { OBJECTIVE FOR } \\
\text { ADOLESCENTS }\end{array}$ & BARRIERS & $\begin{array}{l}\text { SUCCESSFUL PROGRAMME } \\
\text { APPROACHES }\end{array}$ & EXAMPLES \\
\hline \multicolumn{4}{|c|}{ DEMAND FOR CONTRACEPTION } \\
\hline $\begin{array}{l}\text { To foster the desire } \\
\text { to avoid, delay, } \\
\text { space, or limit } \\
\text { childbearing }\end{array}$ & $\begin{array}{l}\text { - Gendered roles (e.g., } \\
\text { expectations to be a wife } \\
\text { and mother) } \\
\text { - The need to prove fertility } \\
\text { - } \quad \text { Religious values } \\
\text { - } \\
\text { Norms of the path to } \\
\text { adulthood }\end{array}$ & $\begin{array}{l}\text { Direct (e.g., school-based } \\
\text { SRH education) and } \\
\text { indirect (e.g., conditional } \\
\text { cash transfers) programmes } \\
\text { that enhance the accept- } \\
\text { ability of avoiding, } \\
\text { delaying, spacing, and } \\
\text { limiting childbearing. }\end{array}$ & $\begin{array}{l}\text { Conditional cash transfers } \\
\text { have transformed life } \\
\text { trajectories of girls in } \\
\text { Mexico and Malawi. }\end{array}$ \\
\hline $\begin{array}{l}\text { To foster the } \\
\text { desire to use } \\
\text { contraception }\end{array}$ & $\begin{array}{ll}\text { - Stigma } \\
\text { - Taboos (communication and } \\
\text { cultural) } \\
\text { - Lack of understanding } \\
\text { (including fear of side- } \\
\text { effects) }\end{array}$ & $\begin{array}{l}\text { SRH education and infor- } \\
\text { mation programmes that } \\
\text { improve the understanding } \\
\text { of contraceptive methods } \\
\text { and SRH. }\end{array}$ & $\begin{array}{l}\text { Life-skills education } \\
\text { and vocational training } \\
\text { programmes in Uganda and } \\
\text { India have been shown to } \\
\text { increase contraceptive use. }\end{array}$ \\
\hline $\begin{array}{l}\text { To foster a sense of } \\
\text { agency in relation } \\
\text { to contraceptive } \\
\text { use }\end{array}$ & $\begin{array}{l}\text { - Early marriage } \\
\text { - } \\
\text { - Semily pressure coercion and/or } \\
\text { violence } \\
\text { - Limited decision-making } \\
\text { autonomy and power }\end{array}$ & $\begin{array}{l}\text { Direct (e.g., school-based } \\
\text { education on sexual } \\
\text { negotiation) and indirect } \\
\text { (e.g., youth development) } \\
\text { programmes that increase } \\
\text { the sense of agency among } \\
\text { girls and women to exert } \\
\text { control over their lives and } \\
\text { make their own decisions. }\end{array}$ & $\begin{array}{l}\text { Engaging adolescents } \\
\text { directly - as well as } \\
\text { their communities - in } \\
\text { Bangladesh and India has } \\
\text { been shown to improve } \\
\text { girls' agency and to prevent } \\
\text { early marriage. }\end{array}$ \\
\hline \multicolumn{4}{|c|}{ SUPPLY OF CONTRACEPTION } \\
\hline $\begin{array}{l}\text { To provide access } \\
\text { to contraceptive } \\
\text { services }\end{array}$ & $\begin{array}{ll}\cdot & \text { Lack of awareness of } \\
& \text { services } \\
\text { - } & \text { Inaccessible location } \\
\text { - } & \text { Inconvenient operating } \\
\text { hours } \\
\text { - } & \text { Costs } \\
\text { - } & \text { Waiting times }\end{array}$ & $\begin{array}{l}\text { SRH education and } \\
\text { information on where and } \\
\text { how to access services } \\
\text { and contraceptive service } \\
\text { provision to increase access } \\
\text { to contraceptive services. }\end{array}$ & $\begin{array}{l}\text { Community-based outreach } \\
\text { involving provision of } \\
\text { information and services } \\
\text { through the national } \\
\text { Health Extension Program } \\
\text { (HEP) led to remarkable } \\
\text { improvements in uptake } \\
\text { of modern contraception } \\
\text { among adolescents in } \\
\text { Ethiopia. }\end{array}$ \\
\hline $\begin{array}{l}\text { To provide } \\
\text { adolescent-friendly } \\
\text { services }\end{array}$ & $\begin{array}{ll}\text { - } & \text { Lack of provider sensitivity } \\
\text { Provider reluctance to offer } \\
\text { contraceptives to adoles- } \\
\text { cents (due to bias) } \\
\text { - } \quad \text { Gender biases } \\
\text { - } \quad \text { Lack of privacy/confidentiality } \\
\text { or out of stocest unavailable } \\
\text { or out }\end{array}$ & $\begin{array}{l}\text { SRH information and } \\
\text { services programmes } \\
\text { to increase provision of } \\
\text { high-quality, youth-friendly } \\
\text { services for adolescents, } \\
\text { tailored to meet adoles- } \\
\text { cents' needs. }\end{array}$ & $\begin{array}{l}\text { Making services responsive } \\
\text { to the needs of adolescents } \\
\text { has been shown to } \\
\text { improve contraceptive } \\
\text { use, thereby preventing } \\
\text { first pregnancies in China } \\
\text { and repeat pregnancies } \\
\text { in Kenya. Evidence from } \\
\text { studies and projects has } \\
\text { been applied at scale in } \\
\text { Colombia, Estonia, and } \\
\text { Malawi. }\end{array}$ \\
\hline
\end{tabular}

Source: Adapted from Glinski et al. (2014) (20)
Table 1 outlines a number of these barriers and responses, and mentions examples of studies and programmes that adolescent uptake approaches to achieve progress in the world.

For example, Estonia implemented a school-based sexuality education programme that was linked to youth-friendly sexual and reproductive health (SRH) services and ensured a supportive policy environment. Rates of abortion and births to adolescents aged 15-19 years were substantially reduced (18). Ethiopia achieved remarkable improvements in uptake of modern contraception among adolescents (from less than $10 \%$ in 2005 to about $25 \%$ in 2011) throu the national Health Extension Program (HEP), which involved recruiting, training, and deploying an all-female local level (19).

CONSIDERATIONS FOR REDUCING EARLY AND UNINTENDED

\section{CIES AMONG}

\section{ADOLESCENTS}

Five elements must be in place in order to apply the evidence to large-scale, national-level programmes:

Collect, analyse, and use accurate and up-to-date data on programme performance, and adolescent sexuality/ fertility to inform the development of laws, policies and strategies that are responsive to the varying needs of
different groups of adolescents based on their social an different groups of adolescents based on their social and aged 15-19 occur within marriage (21). However, in many places, sexually active unmarried adolescents have even higher rates of unmet need for contraception (5). The very different for married and unmarried adolescents. Complementary strategies to respond to the various needs of different populations should be employed in order to leave no one behind

2. Formulate or revise national laws and policies that enhance adolescent access to comprehensive SRH health workers -in the public, private, and nonprofit sectors-to provide comprehensive SRH services including contraceptive and safe abortion (where permitted) services to adolescents, and those that promote access to skills-based health education, hcluding comprehensive widely and support their implementation.

3. Develop national adolescent SRH strategies to include evidence-based and context-specific in budgets to deliver the interventions, and indicators to track progress that are disaggregated by age and socioeconomic status.

4. Implement strategies with careful monitoring of activities, and with the input and expertise of key stakeholders regional level, civil society organizations, United Nations agencies, youth organizations and networks, donor organizations, parents, teachers, and community

5. Conduct periodic programme reviews to identify lessons learned, build on strengths, and address weaknesses.
USEFUL RESOURCES TO INFORM COUNTRY-LEVEL SCALE-UP

OF ADOLESCENT SEXUAL

\section{AND REPRODUCTIVE HEALTH}

\section{PROGRAMMES}

Technical Guidance for Prioritizing Adolescent Health. Every Woman Every Child. 2017 https://Www.unfpa.org/ WEB.pdf

WHO recommendations on adolescent sexual and reproductive health and rights: http://www.who.int/

International technical guidance on sexuality education Educational, Scientific and Cultural Organization UNESCO), 2018. http:///unesdoc.unesco.org/ images/0026/002607/260770e.pd

\section{REFERENCES}

UNICEF. 2016. "Adolescents: Overview," UNICEF Data: Monitoring the Situation of Children and Women [website] unicef.org/topic/adolescents/overview/ accessed 26 June 2017.

2 Darroch, J.E., V. Woog, A. Bankole, and L.S. Ashford. 2016. Adding It Up: Costs and Benefits of Meeting Contraceptive Needs of Adolescents. New York: Guttmacher Institute. hitps://www.guttmacher.org/sites/defaul//iles/report_pd adding-it-up-adolescents-reportpdf, accessed 26 June

Woog, V. and A. Kågesten. 2017. The Sexual and Reproductive Health Needs of Very Young Adolescents Aged 10-14 in Developing Countries: What Does the Evidence Show? New York: Guttmacher Institute. 26 June 2018.

4 Darroch, J.E., S. Audam, and V. Woog. 2016. Adding It Up: costs and Benefits of Meeting the Contraceptive Needs of Adolescents. Supplementary Data Tables. New York: Guttmacher Institute. https://www.guttmacher.org/sites/ un 2016 supplementary_data_tables xlsx, accessed 26 June, 2018

5 V. Woog, S. Singh, A. Browne, J. Philbin. 2015. Adolescent Women's Need for and Use of Sexual and Reproductive Health Services in Developing Countries. New York: Guttmacher insticte. https:/Www.guttmacher.org/sites/ countries.pdf accessed 26 June 2017.

6 WHO. 2017. "Adolescents: Health Risks and Solutions: Fact Sheet." Geneva: World Health Organization. http://www. who.int/me
June 2017 .

WHO. 2011. Unsafe Abortion: Global and Regional Estimates of the Incidence of Unsafe Abortion Geneva: World Health Organization http://ww who.int/reproductivehealth/publications/unsafe abortion/9789241501118/en, accessed 26 June 2017.

8 Birungi, H., C. Undie, I. Mackenzie, A. Katahoire, F. Obare, Early and Unintended Pregnancy: A Review of Country 
Experiences in sub-Saharan Africa. STEP UP and UNESCO Research Report. Strengthening Evidence for Programming on Unintended Pregnancy (STEP UP). Nairobi: Population Council and UNESCO. https:// www.popcouncil.org/uploads/pdfs/2015STEPUP_ EducSectorResp.pdf, accessed 26 June 2017.

9 Undie, C., H. Birungi, G. Odwe, and F. Obare. 2015. Expanding Access to Secondary School Education for Teenage Mothers in Kenya: A Baseline Study Report. STEP UP Research Report. Strengthening Evidence for Programming on Unintended Pregnancy (STEP UP). Nairobi: Population Council. https://www.popcouncil.org/ uploads/pdfs/2015STEPUP_EducTeenMothersKenya.pdf, accessed 26 June 2017

10 UNESCO. 2014. Developing an Education Sector Response to Early and Unintended Pregnancy: Discussion Document for a Global Consultation. Paris: United Nations Educational, and Scientific and Cultural Organization. http://unesdoc. unesco.org/images/0023/002305/230510E.pdf, accessed 26 June 2017

11 UNFPA. 2013. State of the World Population 2013: Motherhood in Childhood - Facing the Challenge of Adolescent Pregnancy. New York: United Nations Population Fund. http://www.unfpa.org/publications/stateworld-population-2013, accessed 26 June 2017.

12 WHO. 2017. Global Accelerated Action for the Health of Adolescents (AA-HA!): Guidance to Support Country Implementation. Geneva: World Health Organization. http://apps.who.int/iris/bitstream/hand le/10665/255415/9789241512343-eng.pdf?sequence=1, accessed 26 June, 2018.

12 Gottschalk LB, Ortayli . Interventions to improve adolescents' contraceptive behaviors in low- and middle-income countries: a review of the evidence base. Contraception. 2014; 90(3):211-25. doi:10.1016/j. contraception.2014.04.017.

13 Govender, D., S. Naidoo, and M. Taylor. 2018. "Scoping review of risk factors of and interventions for adolescent repeat pregnancies: A public health perspective," African Journal of Primary Health Care \& Family Medicine 10(1) doi:https://doi.org/10.4102/phcfm.v10i1.1685.

14 Chandra-Mouli, V., C. Lane, and S. Wong. 2015. "What does not work in adolescent sexual and reproductive health: A review of evidence on interventions commonly accepted as best practices," Global Health: Science and Practice 3(3): 333-340. doi:10.9745/GHSP-D-15-00126.

15 Gottschalk, L.B. and N. Ortayli. 2014. "Interventions to improve adolescents' contraceptive behaviors in lowand middle-income countries: A review of the evidence base," Contraception 90(3): 211-225. doi:10.1016/j. contraception.2014.04.017.

16 Hindin, M.J., A. M. Kalamar, T. A. Thompson, and U.D. Upadhyay. 2016. "Interventions to prevent unintended and repeat pregnancy among young people in lowand middle-income countries: A systematic review of the published and gray literature," Journal of Adolescent Health 59(suppl. 3): S8-S15. doi:10.1016/j. jadohealth.2016.04.021.

17 PRB. 2017. Youth Contraceptive Use: Effective Interventions: A Reference Guide. Washington, DC: Population Reference Bureau. http://www.prb.org/pdf17/ PRB\%20 Youth\%20Policies\%20Reference\%20Guide.pdf, accessed 26 June 2017

18 Haldre, K., K. Part, and E. Ketting. 2012. "Youth sexual health improvement in Estonia, 1990-2009: The role of sexuality education and youth-friendly services," European Journal of Contraception and Reproductive Health Care 17(5): 351-362. doi:10.3109/136251 87.2012.696751.
Authors: Francis Obare, Caroline Kabiru (Population Council); Venkatraman Chandra-Mouli.

This is one of seven Family Planning Evidence Briefs prepared for the Family Planning Summit held in London on July 11, 2017. The briefs highlight evidence and provide research and programme considerations for improving access to family planning and reducing unintended pregnancy. Programme considerations are based on the expert views of the authors, who undertook desk reviews drawing on existing evidence.

\section{Family Planning Evidence Briefs}

- Accelerating uptake of voluntary, rights-based family planning in developing countries (overview) (Updated October 2018)

- Family Planning Financing (Updated October 2018)

- Reducing early and unintended pregnancies among adolescents (Updated October 2018)

- Improving family planning service delivery in humanitarian crises

- Ensuring contraceptive security through effective supply chains

- Expanding contraceptive choice (Updated October 2018)

- Partnering with the private sector to strengthen provision of contraception

The authors alone are responsible for the views expressed in this article and they do not necessarily represent the views, decisions or policies of the institutions with which they are affiliated.

Family Planning Evidence Brief - Reducing early and unintended pregnancies among adolescents: WHO/RHR/18.25

(c) World Health Organization 2018. Some rights reserved. This work is available under the CC BY-NC-SA 3.O IGO license.

For more information, please contact: Department of Reproductive Health and Research, World Health Organization, Avenue Appia 20 $\mathrm{CH}-1211$ Geneva 27, Switzerland

E-mail: reproductivehealth@who.int

Website: www.who.int/reproductivehealth

Twitter: @HRPresearch

This material has been funded by UK aid from the UK government however, the views expressed do not necessarily reflect the UK government's policies.

Prepared July 2017. Updated October 2018

19 Hounton, S., A.J.D. Barros, A. Amouzou, A. Shiferaw, A Maïga, A. Akinyemi et al. 2015. "Patterns and trends of contraceptive use among sexually active adolescents in Burkina Faso, Ethiopia, and Nigeria: Evidence from cross-sectional studies," Global Health Action. 8: 29737. doi:10.3402/ gha.v8.29737.

20 Glinski, A., M. Sexton, S. Petroni. 2014. Understanding the Adolescent Family Planning Evidence Base. Washington, DC: International Center for Research on Women.

21 UNFPA. 2015. Childhood, Not Motherhood: Preventing Adolescent Pregnancy. New York: United Nations Population Fund. http://www.unfpa.org/sites/default/ files/pub-pdf/Girlhood_not_motherhood_final_web.pdf, accessed 6 July 2017 